\title{
A VIDA EM REDE
}

\section{THE NETWORKED LIFE}

\section{Amélia Aben-Athar Olinto RAMOS ${ }^{1}$}

DI FELICE, Massimo; LEMOS, Ronaldo. A Vida em Rede. Campinas: Papirus 7 Mares, 2014.

Resumo: O livro "A vida em rede" é um rico debate sobre os avanços da tecnologia e seus efeitos em nossa vida cotidiana. A internet hoje deve ser pensada como uma nova relação entre o homem e a tecnologia que se apresenta muito mais complexa do que imaginamos. Em breve estaremos diante de uma sociedade hiperconectada.

Palavras-chave: Mídia; Cotidiano; Comunicação.

O livro "A Vida em "Rede", dos autores Massimo di Felice e Ronaldo Lemos, oferece um debate sobre um tema dos mais atuais: a rede e os avanços tecnológicos que provocam mudanças em nossa vida cotidiana, a partir de uma nova perspectiva comunicacional que a Internet nos proporciona. Os autores propõem ao leitor a análise de paradigmas, que vão desde a lógica emissor-receptor, até uma série de conceitos, como a nova esfera pública e a complexa forma de acesso à informação proposta pela tecnologia.

Massimo di Felice é professor da Universidade de São Paulo (USP), doutor em Ciência da Comunicação (USP) e pós-doutor em Sociologia pela Universidade de Paris Descartes. O coautor, Ronaldo Lemos, é professor de Direito da Universidade Estadual do Rio de Janeiro (UERJ) e doutor pela Universidade de São Paulo (USP) nessa mesma área.

Composto por sete capítulos curtos, o livro se desenvolve através de um debate entre Di Felice e Lemos que se estende até o seu final. Partindo dessa apresentação, pode ser dividido em duas partes. A primeira reúne os capítulos: Homo Tecnologicus;

Mestranda do Programa de Pós-graduação em Mídia e Cotidiano da Universidade Federal Fluminense (UFF). ameliaab@ hotmail.com. 
Economia de mercado e redes informativas; Tecnologia e as novas formas de comunicação e participação; e Mercado e democracia nas redes. A segunda reúne outros três capítulos sobre Tecnologias colaborativas, educação e conhecimento; Valor, dinheiro e influência nas redes; e Brasil, direitos e sensorialidade: o futuroje.

Na primeira parte, o debate se inicia atribuindo à Internet não mais apenas o lugar da compra online ou um recurso técnico. Admite-se que hoje em dia ela transcende essas ideias e estabelece entre o homem e a tecnologia uma nova forma de pensar qualquer setor: governo, economia, universidade, sociedade civil, etc. Somos colocados diante de uma nova arquitetura da comunicação. A ideia de que a tecnologia é um mero instrumento externo já não pertence à sociedade atual. As relações através das redes são mais complexas do que imaginamos.

Ao dialogarmos na rede, habitarmos a rede, estamos adquirindo uma nova forma de organização das informações, de nos relacionarmos perante os problemas e também uma nova forma de diálogo com diversos atores e, sobretudo, um novo tipo de inteligência e de conhecimento. (DI FELICE; LEMOS, 2014, p. 12)

Considerando pensadores como Heidegger (apud DI FELICE; LEMOS, 2014), em seu texto "Ensaio sobre a técnica", a essência da técnica não é técnica e a relação entre o humano e a tecnologia não pode ser pensada como uma relação opositiva. Uma interpretação possível "é reconhecer que tudo o que o homem produz, ou melhor, toda a humanidade produzida pelo homem - não só hoje com o digital, mas desde sua origem, foi desenvolvida em diálogo com a técnica e com o meio ambiente" (Ibid., p. 17).

Indo além, no segundo capítulo, sobre a economia de mercado e as novas redes informativas, os autores consideram que, no futuro, a palavra Internet já não estará mais restrita à ideia de rede. Ela contemplará tudo e as telas estarão por toda parte. Estar conectado ou não, não fará mais sentido. Estaremos diante de uma sociedade hiperconectada. No entanto, acredita-se que o Facebook, assim como outras redes sociais que já existiram, poderão desaparecer e outras formas mais interessantes e confiáveis surgirão, atendendo à lógica de mercado, que oferece opções.

Nas redes sociais, assim como no Facebook não há intermediação, os atores têm voz. Segundo Lemos, "não é mais uma ONG que vai até a aldeia indígena ou o 


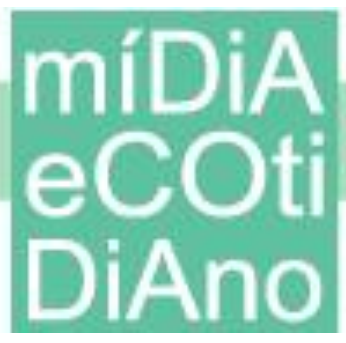

antropólogo e divulga aquela realidade. São os protagonistas eles mesmos agindo, apresentando vários projetos e criando sua própria estratégia por meio da tecnologia e da conectividade" (Ibid., p. 33), possibilitado pelas redes. Isso não significa dizer que o que se lê no Facebook, que dá voz a todos, pode ser considerado como manifestação de uma opinião pública. Segundo Di Felice, a opinião pública das mídias anteriores era criada por líderes, políticos, jornais e jornalistas que a escreviam e publicavam. Assim sendo, refletem que estamos diante de uma esfera pública contemporânea muito mais complexa do que aquela de 15 ou 20 anos atrás.

$\mathrm{Na}$ visão de Di Felice e Lemos sobre a tecnologia e as novas formas de comunicação e participação, os autores se dedicam a pensar e discutir que as redes, de certa maneira, questionam e superam a concepção ocidental de mundo, um mundo analógico. É preciso discutir as redes e não destruir o que há de positivo na concepção de mundo ocidental. "Do ponto de vista do Brasil, do Japão, da Índia, por exemplo, é possível pensar em outras formas de construção de significado, de solução de problemáticas que não sejam ancoradas na epistemologia ocidental nem limitadas à lógica da política e economia ocidental" (Ibid., p. 38).

Tomando como exemplo a ideia, dentro de um contexto tecnológico, de que se pode rever e melhorar o funcionamento das instituições, os movimentos "netativistas" no Brasil e no mundo inteiro surgiram e colocaram em xeque a questão de como são tomadas as decisões. Recusam hierarquização e apresentam um modelo de democracia, no qual não existe um poder central, segundo Di Felice. Desta forma, o modelo de representatividade democrática também está em modificação diante de um mundo conectado.

Sobre o mercado e democracia nas redes, Lemos ressalta como a indústria musical foi transformada definitivamente pela tecnologia, a inclusão digital das camadas mais pobres, desde o Orkut e as lan houses que proporcionaram acessos à informação: livros, games, filmes, músicas e assim por diante.

É muito interessante perceber que cenas culturais periféricas como tecnobrega, lambadão cuiabano, a tchê música, a pisadinha, o funk ostentação em São Paulo, entre vários outros tipos, são hoje as músicas mais populares ouvidas no país. Aliás, as músicas mais populares do Brasil não circulam no 
rádio ou na televisão como costumamos pensar. Elas circulam no You Tube, nas redes sociais e nos celulares e tablets. (Ibid., p. 45)

Os autores acreditam na educação online e especulam por que razões as universidades públicas não disponibilizam suas aulas no Brasil inteiro a custo zero e usam como exemplo outras universidades como: MIT (Instituto de Tecnologia de Massachusetts), Harvard e Stanford. Assim, desenvolvem o capítulo sobre as tecnologias colaborativas, educação e conhecimento. A ideia de trazer a rede para dentro da academia só reforça a intenção de poder gerar informação para todos. Do ponto de vista dos dois escritores, não existe instituição mais hierarquizada que a academia que, para eles, só perde para os militares. O Brasil controla a vida acadêmica dos alunos e professores com a obrigatoriedade de cumprir um currículo estabelecido pelo MEC e impede que as pessoas se envolvam de outra forma para construir o seu próprio conhecimento. Nesse caso, a tecnologia entra como um elemento de erupção muito forte nessa estrutura hierárquica da academia brasileira. Sid Meier, um designer de games, quando perguntado se os games eram o futuro da educação, respondeu: "Não, acho que a educação não tem futuro sem os games".

\footnotetext{
Num ambiente virtual de aprendizagem, o aluno pode continuar a debater o conteúdo, pois não está mais limitado ao tempo da aula presencial; ele tem tutores com quem dialoga; tem formas de avaliação e pode até mesmo interagir com games; tem a possibilidade de criar construções colaborativas de conteúdo com discussões e debates. (Ibid., p. 76)
}

No mundo do valor, dinheiro e influência nas redes, penúltimo capítulo, um importante aspecto sobre as redes está relacionado aos "posts", como os de moda, por exemplo, que estiveram envolvidos em polêmicas e passaram a ser questionados sobre sua legitimidade. Eles parecem ter se tornado uma espécie de representantes das grandes marcas. A cultura midiática de 30 anos atrás expressava confiança em relação à mídia, mas hoje, qualquer informação da TV, do jornal ou da Internet deve ser conferida. Na Internet há dificuldade em definir o que é um discurso publicitário ou um discurso legítimo.

Os autores acreditam que essa dualidade da Internet, que gera dúvida quanto à fonte ou às situações relativas às ofertas do mercado, se diferenciam daquela mídia do passado, pois despertam novas consciências, tornando o consumidor mais capaz de se 


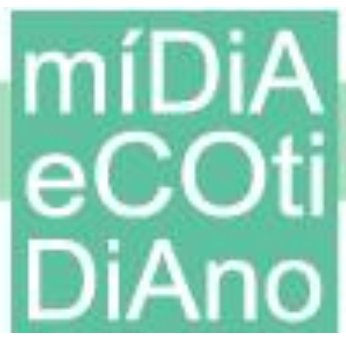

defender dispondo de muito mais armas do que na sociedade anterior. Assim sendo, eles retomam a discussão da participação das universidades públicas na difusão do conhecimento, através de cursos online gratuitos, os Moocs (massive open online courses), facilitando o acesso de setores da população ao ensino universitário e promovendo, através da digitalização, um diálogo mais próximo com a sociedade.

Por fim, o último capítulo, Brasil direitos e sensorialidade: futuroje, aborda uma transformação relacionada ao mundo da rede, que se destaca pelo conhecimento multissensorial; de acordo com os autores, estamos diante de uma época privilegiada, na qual podemos nos deslocar entre esses diversos tipos de arquitetura cognitiva, com diversos tipos de interações e diversos tipos de experiência.

Por outro lado, Lemos destaca que a questão da privacidade vai ser central nas próximas décadas e está relacionada a um dos pilares do estado democrático de direito.

Na medida em que predomina essa ideia de que as liberdades civis são a chave de abóboda da democracia, sem a qual ela não se sustenta, com a certeza de que, se se mexer nela, tudo o mais desaba, precisamos começar a nos preocupar em como traduzir esses direitos para realidade digital. (Ibid., p. 118)

$\mathrm{Na}$ realidade, estamos todos sujeitos a ser vigiados a qualquer tempo no mundo digital. Será necessário pensar um novo tipo de direito, uma vez que o direito público e privado de hoje não está em sintonia com a complexidade das redes. O que está implícito para os autores é que, na realidade, quem deve temer esse acesso irrestrito a dados e informações não são os indivíduos e sim os grandes grupos econômicos, os oligopólios, os poderes políticos.

Desta maneira, a população tem uma grande arma para controlar tudo o que está fazendo. O controle das contas, dos gastos, das decisões, deve ter publicidade, a questão que resta é como, com essa tendência de transparência, que afeta o mundo todo, pode-se preservar a esfera do indivíduo e expor a esfera pública, compartilhando a coisa pública.

Este livro é um importante caminho de reflexão e nos leva a procurar entender o momento que estamos vivendo e para onde estamos caminhando no mundo digital e hiperconectado. O Marco Civil foi aprovado em abril de 2014; se isso tivesse sido feito mais cedo, o Brasil estaria hoje na posição de líder mundial na questão da governança 


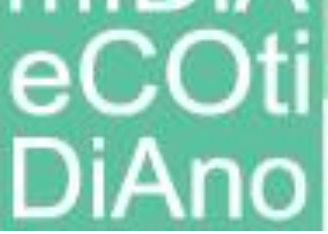

da Internet. No entanto, como escrevem os autores, "O Brasil tem compromisso com uma rede, um país em que a democracia e a liberdade de expressão são princípios constitucionais, em que não há uma tentativa do governo, por várias razões, de controlar o que acontece nas redes" (Ibid., p. 97).

\section{Referências}

DI FELICE, Massimo; LEMOS, Ronaldo. A Vida em Rede. Campinas: Papirus 7 Mares, 2014. 